\title{
ДОСЛІДЖЕННЯ АМІНОКИСЛОТНОГО СКЛАДУ СИРОВИНИ МАТІОЛИ ДВОРОГОÏ (MATTHIOLA BICORNIS (SIBTH. \& SM.) DC.) СОРТУ ЦАРИЦЯ НОЧІ
}

Вступ. Амінокислоти - фрізіологічно важлива група сполук, що бере участь у синтезі й метаболізмі багатьох речовин, здатна підтримувати нормальне фрункціонування органів і систем організму. Амінокислоти та їх похідні давно й есрективно застосовують у медицині. Рослини синтезують усі необхідні їм амінокислоти. Організм людини не може синтезувати всі амінокислоти, яких потребує, частину з них він одержує з їжею. Тому актуальним є дослідження амінокислотного складу рослин.

Мета дослідження - вивчити якісний склад та визначити кількісний вміст амінокислот у сировині матіоли дворогої сорту Цариця ночі.

Методи дослідження. Об'єктами дослідження були обмолочена трава, стебла, корені та насіння матіоли дворогої сорту Цариця ночі. Амінокислотний склад досліджуваних видів сировини визначали методом іонообмінної рідинно-колонкової хроматографії на автоматичному аналізаторі амінокислот.

Результати й обговорення. У сировині матіоли дворогої сорту Цариця ночі, взятої для дослідження, встановлено наявність 18 амінокислот: 7 незамінних, 3 напівзамінних та 8 замінних. Найвищий вміст амінокислот спостерігали в насінні та обмолоченій траві, найнижчий - у коренях. За кількістю в надземній частині рослини домінував пролін. У коренях та насінні найбільше накопичувалася глутамінова кислота. Цистин у обмолоченій траві й стеблах було виявлено в найменшій кількості, гістидин - у коренях, а y-аміномасляну кислоту - в насінні. Сума незамінних амінокислот у досліджуваних видах сировини матіоли дворогої сорту Цариця ночі становила майже 1/3 від загальної суми амінокислот (31,28, 24,69, 28,63 та 29,77 \% відповідно). Серед незамінних амінокислот у обмолоченій траві, стеблах та коренях за вмістом переважали лейцин і лізин, у насінні - лейцин та френілаланін. У найменшій кількості в коренях містилися метіонін та френілаланін, а в обмолоченій траві, стеблах і насінні - метіонін та ізолейцин.

Висновок. Одержані результати буде використано для стандартизації сировини та розробки нових лікарських препаратів рослинного походження на основі комплексу амінокислот матіоли дворогої.

КЛЮЧОВІ СЛОВА: матіола дворога; амінокислотний склад; іонообмінна рідинно-колонкова хроматографія.

ВСТУП. Матіола дворога (Matthiola bicornis (Sibth. \& Sm.) DC.) - однорічна трав'яниста рослина родини капустяні (Brassicaceae Juss.), яка успішно культивується на території України як декоративна рослина. Проте на сьогодні застосування матіоли дворогої обмежується лише традиційною медициною, що зумовлено недостатнім фітохімічним вивченням та відсутністю стандартизації сировини. Враховуючи достатню сировинну базу даної рослини, актуальним $€$ ії більш поглиблене дослідження.

Амінокислоти - фізіологічно важлива група сполук, що бере участь у синтезі й метаболізмі специфічних тканинних протеїнів, інших амінокислот, нуклеїнових кислот, жовчних кислот, антитіл, складних вуглеводів, ензимів, жирів, гормонів, антибіотиків та інших необхідних для (с В. О. Пінкевич, І. О. Журавель, Н. Є. Бурда, 2020. живих організмів сполук, здатна підтримувати нормальне фрункціонування органів і систем організму. Похідними амінокислот є енкесраліни, ендорфіни та інші нейропептиди [1-6].

Амінокислоти та їх похідні давно й ефективно застосовують у медичній практиці у вигляді моно- і комбінованих лікарських препаратів для лікування захворювань серцево-судинної, нервової, травної систем, зміцнення імунної системи, нормального фрункціонування ендокринних залоз, із метою профрілактики атеросклерозу тощо. Рослини синтезують усі необхідні їм амінокислоти. Організм людини не може синтезувати всі амінокислоти, яких потребує, частину з них він одержує з їжею [1-6].

Мета дослідження - вивчити якісний склад та визначити кількісний вміст амінокислот у сировині матіоли дворогої сорту Цариця ночі. 
МЕТОДИ ДОСЛІДЖЕННЯ. Об'єктами дослідження були обмолочена від стебел трава, стебла, корені, заготовлені у фразу цвітіння, та насіння матіоли дворогої сорту Цариця ночі.

Амінокислотний склад досліджуваних видів сировини визначали методом іонообмінної рідинно-колонкової хроматографіії на автоматичному аналізаторі амінокислот АААТ-339M ("Мікротехн", Чехія).

Для визначення суми амінокислот точно зважену наважку повітряно-сухої подрібненої сировини масою близько 100 мг поміщали на дно пробірки з вогнетривкого скла. У пробірку додавали 0,5 мл води очищеної та 0,5 мл концентрованої хлористоводневої кислоти, після чого охолоджували за допомогою суміші сухого льоду з диметилкетоном. Після охолодження для запобігання окисненню амінокислот вакуумним насосом із пробірки викачували повітря. Гідроліз протеїнів проводили хлористоводневою кислотою протягом доби в термостаті з постійною температурою $+106{ }^{\circ} \mathrm{C}$. Після закінчення гідролізу пробірку охолоджували до кімнатної температури та розкривали [7-9].

Вміст пробірки кількісно переносили у скляний бюкс і поміщали у вакуумний ексикатор над гранульованим гідроксидом натрію та видаляли повітря вакуумним насосом. Зразки висушували, після чого в бюкси додавали 3-4 мл деіонізованої води і повторювали процедуру висушування. Підготовлені зразки розчиняли в 0,3 Н літій-цитратному буфері (pH 2,2) і наносили на іонообмінну колонку аналізатора амінокислот (Ostion LGANB), заповнену катіонітом [7-9].

Амінокислоти в елюатах реєстрували методом детекції нінгідрином. На виході з колонки до елюату мікронасосом безперервно подавали нінгідриновий реактив у визначеному співвідношенні з елюатом. Дана суміш по капілярній трубці направлялася в нагрітий до температури +95-98 ${ }^{\circ} \mathrm{C}$ реактор, потім - у кювету. Нінгідрин, взаємодіючи з амінокислотою по аміногрупі, утворює сполуку, що має максимум поглинання при 560 нм (окрім сполук з проліном і оксипроліном, які мають максимум поглинання при 440 нм). Інтенсивність утвореного забарвлення вимірювали за допомогою фотоколориметрування. Сигнали фоотоелемента підсилювали і реєстрували самописним потенціометром у вигляді хроматограми [7-9].

Кількість мікромолей амінокислоти в досліджуваному зразку визначали за відношенням площі піка амінокислоти в досліджуваному зразку до площі піка цієї ж самої амінокислоти в розчині стандартної суміші амінокислот, що відповідає одному мікромолю кількості кожної амінокислоти. Кількісний вміст амінокислоти в міліграмах розраховували, помноживши кількість мікромолей на молекулярну масу амінокислоти [7-9].

РЕЗУЛЬТАТИ Й ОБГОВОРЕННЯ. РеЗУЛЬТаТИ визначення якісного складу та кількісного вмісту амінокислот у сировині матіоли дворогої сорту Цариця ночі наведено в таблиці.

Як видно з таблиці, в обмолоченій траві, стеблах, коренях та насінні матіоли дворогої сорту Цариця ночі встановлено наявність 18 амінокислот: 7 незамінних (лізин, треонін, валін, метіонін, фенілаланін, ізолейцин, лейцин), 3 напівзамінних (аргінін, тирозин, гістидин) та 8 замінних (аспарагінова, глутамінова кислоти, у-аміномасляна кислота (ГАМК), серин, гліцин, аланін, пролін, цистин).

Найвищий вміст амінокислот спостерігали в насінні та обмолоченій траві матіоли дворогої сорту Цариця ночі $(18,958$ і 18,114 мг/100 мг відповідно). У стеблах вміст амінокислот був приблизно у 2,5 раза нижчий (7,633 мг/100 мг). Найменша кількість амінокислот накопичувалась у коренях $(4,710 \mathrm{mr} / 100 \mathrm{мг})$ - приблизно в 4 рази менше, ніж у обмолоченій траві та насінні, й у майже 1,6 раза менше, ніж у стеблах.

За вмістом у надземній частині рослини домінував пролін (1,600 мг/100 мг (20,96 \%) у стеблах та 3,272 мг/100 мг (18,06 \%) у обмолоченій траві). Варто відмітити, що у стеблах вміст цієї амінокислоти був дещо вищий. Глутамінова кислота найбільше накопичувалася в коренях і насінні (0,971 мг/100 мг (20,62 \%) та 3,542 мг/100 мг (18,69 \%) відповідно). В обмолоченій траві й стеблах цистин було виявлено в найменшій кількості $(0,213 \mathrm{мг} / 100 \mathrm{мг}(1,18 \%)$ та 0,083 мг/100 мг $(1,09 \%)$ відповідно). У коренях найнижчим був вміст гістидину $(0,068$ мг/100 мг $(1,44 \%))$, а в насінні - ГАМК $(0,022$ мг/100 мг $(0,11 \%))$.

Амінокислоти можна розташувати в такій послідовності за зменшенням їх вмісту в досліджуваних видах сировини матіоли дворогої сорту Цариця ночі:

обмолочена трава - пролін > глутамінова кислота > аспарагінова кислота > лейцин > серин > аланін > лізин > френілаланін > треонін > аргінін > валін > гліцин > тирозин > ізолейцин > гістидин > метіонін > ГАМК > цистин;

стебла - пролін > глутамінова кислота $>$ аспарагінова кислота > лейцин > аланін > гліцин > серин > лізин > фенілаланін > треонін > валін > аргінін > ізолейцин > ГАМК > тирозин > гістидин > метіонін > цистин;

корені - глутамінова кислота > пролін > acпарагінова кислота > лейцин > аланін > серин > лізин > валін > треонін > гліцин > ГАМК > ізолейцин > фенілаланін > аргінін > цистин > тирозин > метіонін > гістидин; 
Таблиця - Амінокислотний склад сировини матіоли дворогої (Matthiola bicornis (Sibth. \& Sm.) DC.) сорту Цариця ночі

\begin{tabular}{|c|c|c|c|c|c|c|c|c|}
\hline \multirow{2}{*}{$\begin{array}{c}\text { Назва } \\
\text { амінокислоти }\end{array}$} & \multicolumn{2}{|c|}{$\begin{array}{c}\text { Вміст у обмолоче- } \\
\text { ній траві }\end{array}$} & \multicolumn{2}{|c|}{ Вміст у стеблах } & \multicolumn{2}{|c|}{ Вміст у коренях } & \multicolumn{2}{|c|}{ Вміст у насінні } \\
\hline & мг/100 мг & $\begin{array}{l}\text { \% від } \\
\text { суми }\end{array}$ & мг/100 мг & $\begin{array}{l}\text { \% від } \\
\text { суми }\end{array}$ & мг/100 мг & $\begin{array}{l}\text { \% від } \\
\text { суми }\end{array}$ & мг/100 мг & $\begin{array}{l}\text { \% від } \\
\text { суми }\end{array}$ \\
\hline $\begin{array}{l}\text { у-Аміномасляна } \\
\text { кислота }\end{array}$ & 0,266 & 1,47 & 0,167 & 2,19 & 0,206 & 4,38 & 0,022 & 0,11 \\
\hline Лізин* & 1,010 & 5,58 & 0,337 & 4,42 & 0,237 & 5,03 & 0,751 & 3,96 \\
\hline Гістидин ${ }^{\wedge}$ & 0,374 & 2,06 & 0,128 & 1,68 & 0,068 & 1,44 & 0,497 & 2,62 \\
\hline Аргінін ${ }^{\wedge}$ & 0,777 & 4,29 & 0,198 & 2,60 & 0,126 & 2,67 & 2,283 & 12,04 \\
\hline Аспарагінова кислота & 1,534 & 8,47 & 0,862 & 11,30 & 0,503 & 10,68 & 1,254 & 6,62 \\
\hline Треонін ${ }^{\star}$ & 0,829 & 4,58 & 0,285 & 3,74 & 0,220 & 4,67 & 0,814 & 4,29 \\
\hline Серин & 1,031 & 5,69 & 0,387 & 5,07 & 0,259 & 5,50 & 0,972 & 5,13 \\
\hline Глутамінова кислота & 2,625 & 14,49 & 1,378 & 18,05 & 0,971 & 20,62 & 3,542 & 18,69 \\
\hline Пролін & 3,272 & 18,06 & 1,600 & 20,96 & 0,572 & 12,15 & 1,697 & 8,95 \\
\hline Гліцин & 0,728 & 4,02 & 0,392 & 5,13 & 0,215 & 4,57 & 0,931 & 4,91 \\
\hline Аланін & 1,026 & 5,67 & 0,401 & 5,25 & 0,261 & 5,54 & 1,139 & 6,01 \\
\hline Цистин & 0,213 & 1,18 & 0,083 & 1,09 & 0,104 & 2,20 & 0,256 & 1,35 \\
\hline Валін* & 0,749 & 4,14 & 0,280 & 3,66 & 0,223 & 4,74 & 0,641 & 3,38 \\
\hline Метіонін ${ }^{\star}$ & 0,333 & 1,84 & 0,105 & 1,38 & 0,076 & 1,60 & 0,452 & 2,39 \\
\hline Ізолейцин* & 0,505 & 2,79 & 0,175 & 2,29 & 0,166 & 3,53 & 0,513 & 2,71 \\
\hline Лейцин ${ }^{\star}$ & 1,296 & 7,16 & 0,413 & 5,41 & 0,272 & 5,78 & 1,469 & 7,75 \\
\hline Тирозин ${ }^{\wedge}$ & 0,602 & 3,32 & 0,153 & 2,00 & 0,076 & 1,62 & 0,721 & 3,81 \\
\hline Фенілаланін* & 0,944 & 5,21 & 0,290 & 3,79 & 0,155 & 3,29 & 1,004 & 5,30 \\
\hline $\begin{array}{l}\text { Сума незамінних } \\
\text { амінокислот }\end{array}$ & 5,667 & 31,28 & 1,884 & 24,69 & 1,348 & 28,63 & 5,644 & 29,77 \\
\hline $\begin{array}{l}\text { Сума замінних } \\
\text { амінокислот }\end{array}$ & 12,447 & 68,72 & 5,749 & 75,31 & 3,362 & 71,37 & 13,313 & 70,23 \\
\hline Сума & 18,114 & 100,00 & 7,633 & 100,00 & 4,710 & 100,00 & 18,958 & 100,00 \\
\hline
\end{tabular}

Примітка. * - незамінні амінокислоти; ^ - напівзамінні амінокислоти.

насіння - глутамінова кислота > аргінін > пролін > лейцин > аспарагінова кислота > аланін > френілаланін > серин > гліцин > треонін $>$ лізин > тирозин > валін > ізолейцин > гістидин > метіонін > цистин > ГАМК.

Найбільший інтерес для організму людини становлять незамінні амінокислоти. Їх сума в обраних для дослідження видах сировини матіоли дворогої сорту Цариця ночі становила майже 1/3 від загальної суми амінокислот $(31,28$, 24,69, 28,63 та 29,77 відповідно). Серед незамінних амінокислот за кількістю в обмолоченій траві, стеблах і коренях переважали лейцин (1,296 мг/100 мг (7,16 \%), 0,413 мг/100 мг (5,41 \%) та 0,272 мг/100 мг (5,78 \%) відповідно) і лізин (1,010 мг/100 мг (5,58\%), 0,337 мг/100 мг (4,42 \%) та 0,237 мг/100 мг (5,03 \%) відповідно); в насінні - лейцин і френілаланін (1,469 мг/100 мг (7,75 \%) та 1,004 мг/100 мг (5,30 \%) відповідно). У найменшій кількості виявлено метіонін та ізолейцин - в обмолоченій траві, стеблах і насінні (0,333 мг/100 мг (1,84 \%) та 0,505 мг/100 мг (2,79 \%), 0,105 мг/100 мг (1,38 \%) і 0,175 мг/100 мг (2,29\%), 0,452 мг/100 мг (2,39\%) та 0,513 мг/100 мг (2,71 \%) відповідно), метіонін і френілаланін - у коренях (0,076 мг/100 мг (1,60 \%) та 0,155 мг/100 мг (3,29 \%) відповідно).
Лейцин бере участь у забезпеченні азотної рівноваги, обміні протеїнів, вуглеводів, є джерелом енергії для м'язів на клітинному рівні. Необхідний для побудови і розвитку м'язової тканини, зміцнення імунної системи. Стимулює секрецію інсуліну, сприяє загоєнню ран, зрощенню кісток. Запобігає надмірному синтезу серотоніну [2, 3, $5,10]$. Лізин сприяє накопиченню кальцію в організмі, забезпечує належне його засвоєння, $€$ попередником карнітину, бере участь в утворенні колагену, продукуванні антитіл, гормонів та ензимів $[2,6,10]$. Фенілаланін стимулює продукування щитоподібною залозою тиреоїдних гормонів, бере участь у синтезі таких протеїнів, як інсулін, папаїн та меланін, покращує пам'ять, увагу, настрій, розумову активність, ясність і гостроту мислення. 3 більшої частини фенілаланіну синтезується тирозин, з якого, у свою чергу, синтезуються нейромедіатори дофамін, адреналін і норадреналін. Фенілаланін є основою для синтезу ендорфінів, з нього утворюється фенілетиламін (міститься в шоколаді). Сприяє поліпшенню секреторної функції підшлункової залози і печінки. У молекулі гемоглобіну забезпечує контакти з плоскою структурою гему [2, 6, 10]. Глутамінова кислота бере участь у процесах утворення глікогену з глюкози, є сполучною 
ланкою між обміном вуглеводів і нуклеїнових кислот, бере участь у знешкодженні аміаку. Підтримує дихання клітин головного мозку, стимулює окиснювальні процеси. Використовується при лікуванні деяких захворювань [2, 3, 5, 11]. Пролін $є$ основною складовою колагену і сполучної тканини, відповідає за нормальну роботу серцевого м'яза, опорно-рухового апарату, пружність і еластичність шкіри, сприяє швидкому відновленню зв'язок і шкірних покривів $[1,2,5,6]$.

ВИСНОВКИ. 1. Методом іонообмінної рідинно-колонкової хроматографрії на автоматичному аналізаторі амінокислот досліджено якісний склад та визначено кількісний вміст амінокислот обмолоченої трави, стебел, коренів та насіння матіоли дворогої сорту Цариця ночі.

2. У досліджуваних видах сировини встановлено наявність 18 амінокислот: 7 незамінних 3 напівзамінних та 8 замінних. Найбільший вміст амінокислот спостерігали в насінні та обмолоче- ній траві, найменший -у коренях. За кількістю в надземній частині рослини домінував пролін. У коренях та насінні найбільше накопичувалася глутамінова кислота. В обмолоченій траві та стеблах у найменшій кількості було виявлено цистин, у коренях - гістидин, а в насінні - ГАМК. Вміст незамінних амінокислот у досліджуваних видах сировини матіоли дворогої сорту Цариця ночі становив майже 1/3 від загальної суми амінокислот (31,28, 24,69, 28,63 та 29,77 відповідно). Серед незамінних амінокислот в обмолоченій траві, стеблах та коренях переважали лейцин і лізин, у насінні - лейцин та френілаланін. Метіонін та ізолейцин в обмолоченій траві, стеблах та насінні, метіонін і фенілаланін -у коренях містилися в найменшій кількості.

3. Одержані результати буде використано для стандартизації сировини та розробки нових лікарських препаратів рослинного походження на основі комплексу амінокислот матіоли дворогої.

\section{СПИСОК ЛІТЕРАТУРИ}

1. Wu G. Amino acids: metabolism, functions, and nutrition / G. Wu // Amino Acids. - 2009. - No. 37 (1). P. 1-17.

2. Гараева С. Н. Аминокислоты в живом организме / С. Н. Гараева, Г. В. Редкозубова, Г.В.Постолати. - К. : Б. и., 2009. - 552 с.

3. Ісюк М. В. Дослідження амінокислотного складу герані сибірської / М. В. Ісюк, І. Л. Бензель, Л. В. Бензель // Актуальні питання фрармацевтичної і медичної науки та практики. - 2012. - № 3 (10). - С. 4-6.

4. Кініченко А. О. Дослідження амінокислотного складу Portulaca oleracea L. та Portulaca grandiflora Hook / А. О. Кініченко // Pharmaceutical review. - 2016. № 4. - C. 5-7.

5. Дроздова И. Л. Аминокислотный состав травы икотника серого / И. Л. Дроздова, Т. И. Лупилина // Вестн. ВГУ. Серия “Химия. Биология. Фармация”. 2015. - № 1. - С. 125-128.

6. Лысиков Ю. А. Аминокислоты в питании человека / Ю. А. Лысиков // Эксперим. и клинич. гастроэнтерология. - 2012. - № 2. - С. 88-105.

\section{REFERENCES}

1. Wu, G. (2009). Amino acids: metabolism, functions, and nutrition. Amino Acids, 37 (1), 1-17.

2. Garaeva, S.N., Redkozubova, G.V., \& Postolati, G.V. (2009). Aminokisloty v zhivom organizme [Amino acids in a living organism]. Kyiv [in Russian].

3. Isyuk, M.V., Benzel, I.L., \& Benzel, L.V. (2012). Doslidzhennia aminokyslotnoho skladu herani sybirskoi
7. Использование нингидриновой реакции для количественного определения $\alpha$-аминокислот в различных объектах : метод. рек. / А. В. Симонян, А. А. Саламатов, Ю. С. Покровская, А. А. Аванесян. Волгоград : Изд-во ВолГМУ, 2007. - 106 с.

8. Іосипенко О. О. Вивчення амінокислотного складу листя кабачків / І. О. Іосипенко, В. С. Кисличенко, 3. І. Омельченко // Мед. та клініч. хімія. - 2020. 22, № 2 (84). - C. 72-80.

9. Сорочан О. О. Методи аналізу амінокислот : навч.-метод. посіб. / О. О. Сорочан, Н. І. Штеменко. Д. : РВВ ДНУ, 2005. - 60 с.

10. Аминокислоты глазами химиков, фрармацевтов, биологов : в 2 т. / [А. О. Сыровая, Л. Г. Шаповал, В. А. Макаров и др.]. - Х. : Щедра садиба плюс, 2015. 2. $-268 \mathrm{c}$

11. Аминокислоты глазами химиков, срармацевтов, биологов : в 2 т. / [А. О. Сыровая, Л. Г. Шаповал, В. А. Макаров и др.]. - Х. : Щедра садиба плюс, 2014. 1. $-228 \mathrm{c}$

[Study of the amino acid composition of Siberian geranium]. Aktualni pytannia farmatsevtychnoi i medychnoi nauky ta praktyky - Current Issues in Pharmacy and Medicine: Science and Practice, 3 (10), 4-6 [in Ukrainian].

4. Kinichenko, A.O. (2016) Doslidzhennia aminokyslotnoho skladu Portulaca oleracea L. ta Portulaca grandiflora Hook [Research of amino acid composition 
of Portulaca oleracea L. and Portulaca grandiflora Hook]. Farmatsevtychnyi chasopys - Pharmaceutical Review, (4), 5-7 [in Ukrainian].

5. Drozdova, I.L. \& Lupilina, T.I. (2015). Aminokislotnyy sostav travy ikotnika serogo [The amino acid composition of berteroa incana herb]. Vestnik VGU. Seriya: Khimiya. Biologiya. Farmatsiya - Proceedings of Voronezh State University. Series: Chemistry. Biology. Pharmacy, (1), 125-128 [in Russian].

6. Lysikov, Yu.A. (2012). Aminokisloty v pitanii cheloveka[Amino acids in human nutrition]. Eksperimentalnaya i klinicheskaya gastroenterologiya - Experimental and Clinical Gastroenterology, (2), 88-105 [in Russian].

7. Simonyan, A.V., Salamatov, A.A., Pokrovskaya,Yu.S., \& Avanesyan, A.A. (2007). Ispolzovanie ningidrinovoy reaktsii dlya kolichestvennogo opredeleniyaa-aminokislot $v$ razlichnykh obyektakh [The use ofninhydrin reaction for the quantitative determination of $\alpha$-amino acids in various objects]. Volgograd: Izdatelstvo VolGMU [in Russian].
8. losypenko, O.O., Kyslychenko, V.S., \& Omelchenko Z.I. (2020). Vyvchennia aminokyslotnoho skladu lystia kabachkiv [Study of the amino acid composition of zucchini leaves]. Medychna ta klinichna khimiia - Medical and Clinical Chemistry, 22 (2), 72-80 [in Ukrainian].

9. Sorochan, O.O., \& Shtemenko, N.I. (2005). Metody analizu aminokyslot [Methods of amino acid analysis]. Dnipro: RVV DNU [in Ukrainian].

10. Syrovaya, A.O., Shapoval, L.G., Makarov, V.A., Petyunina, V.N., \& Graboveckaya E.R. (2015). Aminokisloty glazami khhimikov, farmatsevtov, biologov: $v 2-h t$. Tom 2 [Amino acids through the eyes of chemists, pharmacists, biologists: in 2 vol. Vol. 2]. Kharkiv: Shchedra sadyba plius [in Russian].

11. Syrovaya, A.O., Shapoval, L.G., Makarov, V.A., Petyunina, V.N., \& Graboveckaya, E.R. (2014). Aminokisloty glazami khimikov, farmatsevtov, biologov: $v$ 2-h $t$. Tom 1 [Amino acids through the eyes of chemists, pharmacists, biologists: in 2 vol. Vol. 1]. Kharkiv: Shchedra sadyba plius [in Ukrainian].

\section{ИССЛЕДОВАНИЕ АМИНОКИСЛОТНОГО СОСТАВА СЫРЬЯ МАТТИОЛЫ ДВУРОГОЙ (МАTTHIOLA ВICORNIS (SIBTH. \& SM.) DC.) COРTА ЦАРИЦА НОЧИ}

\section{Резюме}

Вступление. Аминокислоты - фризиологически важная группа соединений, которая участвует в синтезе и метаболизме многих веществ, способна поддерживать нормальное фуннционирование органов и систем организма. Аминокислоты и их производные давно и эффрективно применяют в медицине. Растения синтезируют все необходимые им аминокислоты. Организм человека не может синтезировать все аминокислоты, в которых нуждается, часть из них он получает с пищей. Поэтому актуальным является исследование аминокислотного состава растений.

Цель исследования - изучить качественный состав и определить количественное содержание аминокислот в сырье маттиолы двурогой сорта Царица ночи.

Методы исследования. Объектами исследования были обмолоченная трава, стебли, корни и семена маттиолы двурогой сорта Царица ночи. Аминокислотный состав исследуемых видов сырья определяли методом ионообменной жидкостно-колоночной хроматографрии на автоматическом анализаторе аминокислот.

Результаты и обсуждение. В сырье маттиолы двурогой сорта Царица ночи, взятом для исследования, установлено наличие 18 аминокислот: 7 незаменимых, 3 полузаменимых и 8 заменимых. Самое высокое содержание аминокислот наблюдали в семенах и обмолоченной траве, самое низкое - в корнях. По количеству в надземной части растения доминировал пролин. В корнях и семенах больше всего накапливалась глутаминовая кислота. Цистин в обмолоченной траве и стеблях был обнаружен в наименьшем количестве, гистидин - в корнях, а у-аминомасляная кислота - в семенах. Сумма незаменимых аминокислот в исследуемых видах сырья маттиолы двурогой сорта Царица ночи составляла почти 1/3 от общей суммы аминокислот (31,28, 24,69, 28,63 и 29,77 \% соответственно). Среди незаменимых аминокислот в обмолоченной траве, стеблях и корнях по содержанию преобладали лейцин и лизин, в семенах - лейцин и фенилаланин. В наименьшем количестве в корнях содержались метионин и фенилаланин, а в обмолоченной траве, стеблях и семенах - метионин и изолейцин.

Вывод. Полученные результаты будут использованы для стандартизации сырья и разработки новых лекарственных препаратов растительного происхождения на основе комплекса аминокислот маттиолы двурогой.

КЛЮЧЕВЫЕ СЛОВА: маттиола двурогая; аминокислотный состав; ионообменная жидкостно-колоночная хроматограсрия. 


\title{
RESEARCH OF AMINO ACID COMPOSITION OF MATTHIOLA BICORNIS (SIBTH. \& SM.) DC. QUEEN OF THE NIGHT CULTIVAR RAW MATERIALS
}

\begin{abstract}
Summary
Introduction. Amino acids are a physiologically important group of compounds, involved in the synthesis and metabolism of many substances, able to maintain the normal functioning of organs and systems of the body. Amino acids and their derivatives have long been used effectively in medicine. Plants synthesize all the amino acids they need. The human body cannot synthesize all the amino acids it needs, some of which it gets from food. Therefore, the study of the amino acid composition of plants is relevant.

The aim of the study - to learn the qualitative composition and determine the quantitative content of amino acids in the raw material of the Matthiola bicornis (Sibth. \& Sm.) DC. Queen of the Night cultivar.

Research Methods. The objects of the study were threshed grass, stems, roots and seeds of Matthiola bicornis (Sibth. \& Sm.) DC. Queen of the Night cultivar. The amino acid composition of the studied types of raw materials was determined by ion-exchange liquid column chromatography on an automatic amino acid analyzer.

Results and Discussion. In the raw material of Matthiola bicornis (Sibth. \& Sm.) DC. Queen of the Night cultivar, taken for research, the presence of 18 amino acids was established: 7 essential, 3 semi-essential and 8 essential. The highest content of amino acids was observed in seeds and threshed grass, the lowest - in the roots. Proline dominated the number in the aboveground part of the plant. Glutamic acid accumulated the most in roots and seeds. Cystine in threshed grass and stems was found in the smallest amount, histidine - in the roots, and gamma-aminobutyric acid (GABA) - in the seeds. The amount of essential amino acids in the studied types of raw materials of Matthiola bicornis (Sibth. \& Sm.) DC. Queen of the Night cultivar was almost 1/3 of the total amount of amino acids (31.28 \%, $24.69 \%, 28.63 \%$ and $29.77 \%$, respectively). Among the essential amino acids in threshed grass, stems and roots, leucine and lysine predominated in content, and leucine and phenylalanine in seeds. Methionine and phenylalanine were present in the smallest amounts in the roots, and methionine and isoleucine in the threshed grass, stems and seeds.
\end{abstract}

Conclusions. The obtained results will be used for standardization of raw materials and development of new drugs of plant origin based on the amino acid complex of Matthiola bicornis (Sibth. \& Sm.) DC.

KEY WORDS: Matthiola bicornis; amino acid composition; ion exchange liquid column chromatography. 